\title{
Personal savings and household investments: a cohort study among primary school teachers
}

\author{
Emmanuel Akeny $^{1 *}$, David Mwesigwa ${ }^{2}$
}

Faculty of Management Sciences, Lira University, Lira, Uganda ${ }^{1,2}$ emka2010@ gmail.com ${ }^{1 *}$,dmwesigwa@Lirauni.ac.ug ${ }^{2}$

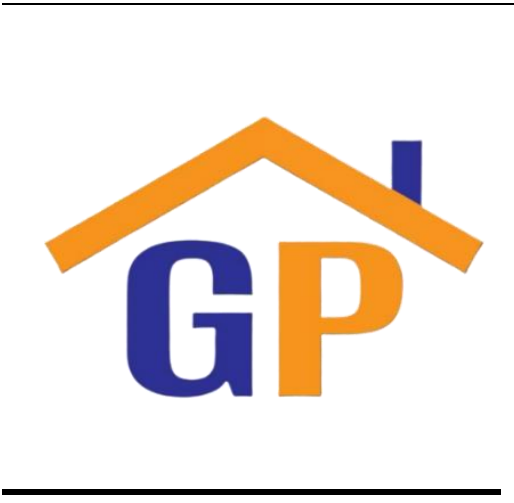

Article History

Received on 22 February 2021

$1^{\text {st }}$ Revision on 2 March 2021

$2^{\text {nd }}$ Revision on 3 March 2021

Accepted on 4 March 2021

\begin{abstract}
Purpose: This study aimed to determine the relationship between personal savings and household investments among a cohort of primary school teachers in Lira city.
\end{abstract}

Research methodology: The study used a cross-sectional survey design with a quantitative research approach. Data were collected from a sample of 103 respondents with the period between October 2020 and January 2021 using self-administered questionnaires. The Content Validity Index was used to establish validity, while the Cronbach's Alpha Coefficient was used to test reliability.

Results: Using descriptive and inferential statistics, the results suggest that civil servants' personal financial planning is high due to personal savings. Also, the level of household investment is high and the correlation reveals that the relationship between private savings and household investment is very weak and negative.

Limitations: This study focused on personal savings only, yet other constructs affect household investments.

Contribution: This study's results help civil servants in Lira city and Uganda in general since personal savings are an essential factor to household investments.

Keywords: Personal savings, Household investment, Primary teacher, Financial planning, Lira

How to cite: Akeny, E., \& Mwesigwa, D. (2020). Personal savings and household investments: a cohort study among primary school teachers. Annals of Management and Organization Research, 1(4), 261-270.

\section{Introduction}

Savings is the portion of income not spent on current expenditures (Kingsley, 2010). Because a person does not know what will happen in the future, money should be saved to pay for unexpected events or emergencies. Investopedia defines Savings as the amount left over after an individual's consumer expenditure is subtracted from the amount of disposable income earned in a given period. Savings can be used to increase revenue through investing in different investment vehicles. Finance is an integral part of everyone's life and financial principles are based on pure and simple common sense. The ability to make financially intelligent decisions is financial planning.

Personal savings include saving households but not of businesses or government and can have a significant impact on both the individual and economy-wide levels in the long and short terms (Stupak, 2018). Thus, saving is a critical component of financial planning. This is because although earned income is fixed and regular, proper planning of the household expenses can release some money to be saved. At low income levels, many people find it difficult to save (Finscope, 2018) but as the income level increases, individuals and households can save more (Keynes, 1936). This conforms to the Keynesian theory on the marginal propensity to save which states that the higher the income for an individual, the higher the marginal propensity to keep as the ability to satisfy needs increases with income. In other words, each additional shilling is less likely to be spent as an individual becomes wealthier. Savings can be formal or informal. Formal savings are when individuals or households save 
their money with registered financial institutions while informal savings are when individuals or households save with local groups or other people. The outcomes from a FinScope 2018 survey reveal that $50 \%$ of those that save do so casually with a savings group or entrusting it to a member in a community for safety, $34 \%$ of those that save, do so with recognised establishments such as commercial banks, SACCOs, or microfinance institutions. In Lango, only $11 \%$ of the adult population bank with a commercial bank (Finscope, 2018). Savings tends to empower individuals to invest in assets.

A study by Chalicha (2015) reveals that SACCOS has empowered civil servants economically and socially by acquiring fixed assets such as buildings, establishing new businesses, and enhancing household well-being. When empowered to save, civil servants can convert their salaries into household investments. It is essential to find out whether such effects are being realized with Ugandan civil servants. Sawsdpeera and Pandey (2012) examined the determinants of saving among salaried individuals in Thailand. Using a cross sectional survey and mixed approach, 409 respondents were interviewed and the findings indicted that greater earnings suggest not only a greater volume of saving but likewise a greater volume of overheads for their standard of living and or additional community overheads that they have to incur for their prominence in public. Consequently, the volume of saving can be greater, but the percentage of saving to earnings may not automatically be more significant.

According to a study by Ellis, Lemma, and Rud (2010) based on data from the FinScope Kenya (2006 and 2009) surveys as well as the Tanzania 2006 survey, the most common reasons for saving and borrowing were for consumption purposes, with meeting day-to-day expenses and meeting household needs being the most important reasons. This is supported by Finscope's (2018) findings, which show that 54 percent (10 million) of Ugandan adults save or put money away intending to continue to do so in the future to ensure that the amount grows. It goes on to say that the majority of savers (63 percent) are doing so to ensure that they can cover day-to-day and unexpected expenses during periods of low income. According to the report, $46 \%$ of Ugandans do not save because they have no money left after expenses. In a country, household saving is a type of internal capital accumulation. The amount of money saved by households can be used to define a country's growth (Suppakitjarak \& Krishnamra, $\underline{2015)}$.

The capacity to save among individuals and households varies differently across nations and communities. Compared to other countries like China where the domestic savings rate is the highest in the world and it surpasses the investment share in GDP, which is also very high by international standards (Cristadoro \& Marconi, 2012), the savings culture in Uganda is rather poor (Ahimbisibwe \& Mafabi, 2017). Statistics from Bank of Uganda (BoU) and Uganda Bureau of Statistics (UBOS) indicate that Uganda's saving culture is terrible, with only 12 percent of the population have bank accounts. At the same time, BoU research shows that just about $3-5 \%$ of Ugandans save their monthly earnings on a regular basis. This is in agreement with UNHS (2017) Report which reveals that $96 \%$ of Ugandans income is spent on consumer goods and only $4 \%$ is saved or invested. Savings is affected by uncontrolled expenses in consumption which have direct implications on investments/production. While consumption may provide immediate satisfaction, savings for investments require a delay in gratification before they begin to satisfy. Most household studies in Uganda have simply studied how households/individuals save or spend their income without determining whether the concept of financial planning is used and how they affect household investment. Most of the studies also target the general population, with no study directly determining personal savings among civil servants. This provides substantial merit for this study.

\section{Literature review and hypothesis development}

\subsection{Key household investments}

2.1.1. Savings

This is the portion of disposable income not consumed. In the General Theory, Keynes (1936) observed that the Marginal Propensity to Save (MPS) increases with an increase in revenue. This agrees with Sawsdpeera and Pandey (2012), which revealed that a person's educational level had a considerably 
confident relation with the regular recurrent volume of savings. Savings with a formal or informal institution is the first step to household investments.

\subsubsection{Real estate}

The yearly requirement for first-hand accommodation for the whole nation is projected at 200,000 of which 135,000 are in countryside and 65,000 in built-up zones ensuing from the population increase of $3.2 \%$ (MoLHUD, 2016). Housing has the potential of becoming the engine that drives the process of sustainable socio-economic development in any country if deliberately targeted. It has also been observed that Housing development has significant backward and forward linkages with capacity to generate employment and enhancement of household income with long term passive residual income that can meet the family needs upon the retirement of the household head. The (MoLHUD, 2016) further notes that demand for rental housing is increasing, especially in urban areas, as an alternative mode of accessing housing. Civil servants can invest their income into low-cost rental units with high occupancy rates.

\subsubsection{Commercial agriculture}

Agriculture is the backbone of Uganda's economy, employing an estimated $73 \%$ of the population (NAADS, 2017). The majority of those engaged are in subsistence agriculture (68\%) with only a fraction engaged in commercial agriculture (ASSP , 2016). Commercial agriculture involves the production of high-value products and value addition activities in the agricultural value chains. Savings from Civil servant can be invested in poultry production, horticulture, oilseed production which all have ready markets.

\subsection{Principles of investment}

The term investing could be associated with the different activities, but the common target in these activities is to employ the money during the time period seeking to enhance the investor's wealth (Mario, 2019). Funds to be invested come from assets already owned, borrowed money and savings. Individuals/families forego consumption and invest their savings expecting to enhance their future consumption possibilities by increasing their wealth. Studies by Dablar, (2014) and Mario, (2019) reveal that by postponing consumption in the present day and financing their investments, shareholders anticipate to increase their impending consumption opportunities by growing their affluence. There are some key principles that applies to civil servants and all who invest into physical and financial assets.

a) Having a clear financial plan - A clear, appropriate and well thought out plan for the type of investment an individual is interested in is very important. This is because the financial plan takes stock of the current income level and how much of this income can be saved to provide the type of household investment. Defining goals clearly and being realistic about ways to achieve them can help protect investors from common mistakes that derail their progress.

b) Start investing early - Getting an early start on investing is one of the best ways to build wealth (Dablar, 2014). Investing for a longer period of time has more advantages than waiting till when an employee has large volumes of money. This is due to the power of compound interest which creates a snowballing effect of the financial returns.

c) Saving regularly - A regular investment plan allows you to choose when and how often you make contributions to ensure that investing remains a priority throughout the year. The amounts saved can be little but sufficient to meet the financial goals of the individual. According to Donaldson (2011), it is vital to know how much you need to begin saving today in order to have a large enough investment portfolio to support your future goal.

d) Diversify to manage risks - Diversification is a powerful strategy for managing traditional risks. In investing, one of the easiest ways to improve the probability of success is to take advantage of diversification opportunities through investing in different asset classes, geographical markets and industries. A civil servant can invest in real estate, milling machines, motorcycles, forestry, and others. These are affected by different cycles of climatic and economic factors.

\subsection{Civil servants}

According to MoPS (2019), the total number of civil servants on the government payroll is 318,342 with $37.8 \%$ female and $62.2 \%$ male. The number of primary school teachers on the government payroll 
is which is about 125,883 , which is about $39 \%$ of civil servants. According to Young (2019) $82 \%$ of these possess national certificates and diplomas obtained after $\mathrm{O}$ level education.

\subsection{The life cycle theory}

Roscoe, Eckstein, Blome \& Goellner (2020) proposed the life cycle theory relating it to the individual's consumption and savings. According to this theory, an individual's spending and saving decisions are based on their total lifetime earnings and spending behavior, not just their annual needs. In principle, people can choose to move funds from periods of high income to periods of low income as long as they receive more than is needed to meet basic needs. The so-called "smoothing of lifetime income" is perhaps the most well-known explanation for working-age people to contribute to a pension. This theory assumes an investor living through the three stages of youth, prime earning years and retirement. In period 1, the income and expenses are low while in period 2, he/she earns either high or low income, and in period 3 he/she enjoys either good or poor health. The consumption model can explain this theory:

$\mathrm{C}=(\mathrm{W}+\mathrm{RY}) / \mathrm{T}$ and therefore savings function derived as:

$\mathrm{S}=(\mathrm{W}+\mathrm{RY}) / \mathrm{T}$

$\mathrm{W}$ is the initial endowed wealth

$\mathrm{R}$ is the number of years earning labour income

$\mathrm{Y}$ is labour income

$\mathrm{T}$ is the life expectancy of the individual

$\mathrm{S}$ is savings from the second model

According to Jia, Li, Bian \& Gan (2019), financial planning would therefore help an individual to decide on how much to save or borrow and how to invest any savings, not just today (in period 1) but in the future (period 2), and how much he should withdraw in retirement. It identifies Social security as the most significant criteria for the meeting the financial welfare of elderly people. The lifecycle model hypothesizes that individuals are forward looking at choosing how much of the resources they will receive over their lifetime they will consume in each period of their life. The theories assumption that individuals will save a portion of their income above basic needs from smoothing future lifetime challenges does not hold for some people. NSSF (2018) found that most individuals would not want to contribute to a pension fund unless mandatorily compelled and $80 \%$ of those who save spend all their savings in a year after receiving the retirement package. Saving, therefore, does not seem to smooth the rough edges of old-age financial demands.

\subsection{Purpose and objectives of the study}

This study aimed to determine the relationship between personal savings and household investments among a cohort of primary school teachers in Lira city. Three objectives informed the study, namely: (a) to determine the level of personal savings among primary school teachers in Lira central division; (b) to determine the level of household investments among primary school teachers in Lira central division; and (c) to determine the relationship between personal savings and household investments among primary school teachers in Lira central division.

\section{Research methodology}

The unit of analysis in this study was primary school teachers. The study adopted a cross-sectional survey design with a purely quantitative research approach and the study population was 168 primary school teachers. The study adopted Krejcie and Morgan's (1970) table to decide on the representative size. Based on the table, the minimum sample size for a population of 168 was 118 respondents. A simple random sampling using the lottery method was used to select the teachers. A simple random selection is where eligible participants are randomly picked from the sample so that any individual has an equal chance of being selected from the population (Creswell, 2012). The study variables were personal savings and household investments. In order to measure the variables, the study will use questions to elicit responses that capture an understanding and application of the basic concepts on personal savings, personal cash flow and personal debt management using constructs employed by Hilgert and Hogarth, (2002) from the University of Michigan. Personal savings will be measured using a five point Likert scale $1=$ strongly disagree, $2=$ Disagree, $3=$ Not sure, $4=$ Agree, $5=$ strongly agree 
basing on personal saving rate. The savings rate is the percentage of disposable personal income that a person saves rather than spend on consumption. It is the proportion of total personal saving to total disposable income. The key indicators of household investment as reported by UNHS 2017 are savings, real estate and commercial agriculture. This is adopted from Hilgert and Hogarth, 2002 in their work on Household Financial Management: The Connection between knowledge and behaviour. Content validity was established by calculating the Content Validity Index (CVI). As a rule of the thumb, a CVI of 0.70 and above is acceptable. The instrument was pilot-tested by administering the questionnaire to 10 primary school teachers. Basing on the results, the Cronbach's Alpha Coefficient was applied to examine the reliability. Gliem and Gliem (2003) reveal that Cronbach's alpha is a measure of reliability that entails only a particular test to achieve a distinctive approximation of a specific test's consistency.

\section{Results and discussions}

Descriptive statistical techniques are statistical measures that portray the nature, attributes and characteristics of the problem. This study employed descriptive measures of mean and standard deviation to describe personal financial planning and household investments. Mean scores facilitated in understanding the state of personal financial planning and the level of household investments among the selected civil servants. To ease the interpretation of mean scores relating to personal financial planning, the researcher used the following range of mean scores to interpret personal financial planning. The mean scores less than 2.500 were interpreted as 'low personal financial planning'. Mean scores ranging from 2.500 through 3.500 were interpreted as 'moderate personal financial planning. Mean scores above 3.500 were interpreted as 'high personal financial planning.' The standard deviations close to zero indicate consistency of opinions on personal financial planning while standard deviations far away from zero indicate inconsistency of opinions on personal financial planning.

\begin{tabular}{lcc} 
Table 1. Level of personal savings among primary school teachers in Lira city $(N=103)$ \\
\hline Descending means & Mean $(\boldsymbol{\mu})$ & Std. Dev. \\
1. I know how much to save in order to achieve my financial goal & 4.379 & 0.794 \\
2. I always save before spending & 4.330 & 0.933 \\
3. My income is enough to be saved & 4.311 & 0.780 \\
4. I am consistent in my monthly savings & 4.214 & 0.836 \\
5. In order to save, I reduce or eliminate some expenses & 4.117 & 0.855 \\
6. My monthly saving is less than half of my income & 4.049 & 1.141 \\
7. My savings is used for the intended purpose & 4.000 & 1.038 \\
8. My savings is kept in a secure place e.g. the bank & 3.942 & 1.092 \\
9. I normally set aside a portion of my income to be saved every month & 3.903 & 1.142 \\
Overall average & $\mathbf{4 . 1 3 8}$ & $\mathbf{0 . 9 5 7}$ \\
\hline
\end{tabular}

From table 1 above, it was established that the level of personal savings $(\mu=4.138$; std. dev. $=.957)$ to be high. This was indicated majorly by aiming at saving a certain amount to meet a financial goal $(\mu=$ 4.379; std. dev. =.794), saving before spending $(\mu=4.330$; std. dev. $=.933)$, and saving monthly and consistently $(\mu=4.214$; std. dev. $=.780)$. The statistics appear to suggest that participants were saving prudently basing on their claim that their income was enough to be saved. However, the standard deviations suggest that different opinions regarding setting aside a portion of their income for saving every month $(\mu=3.903$; std. dev. $=.1 .142)$. The statistics imply that much as attempts to save seem to exist, participants' incomes are not adequate to maintain a regular portion of the income into savings. This is likely because the savings are mostly to smoothen the rough edges of daily life. When they are hit hard, then the savings reduce or disappear, a finding in agreement with Finscope (2018) which found most savers (63\%) are saving for consumption levelling resolves i.e. guaranteeing that they can shield routine as well as unforeseen expenditures throughout the periods of low income.

Based on the aggregated mean scores of each construct: personal savings ( $\mu=4.138$; std. dev. $=.957$ ), the researchers conclude that personal financial planning among civil servants is seemingly high due to personal savings. The relatively high level of savings seems to be spurred by the many saving groups, SACCOS, and saving rounds. These savings should be able to translate into household investments, a 
finding that concurs with FinScope 2018 survey which revealed that $50 \%$ of savers save casually with savings group or entrusting it to somebody in the public for safety. It further agrees with Chalicha (2015) who found that civil servants can convert their salaries into household investments when empowered to save.

The researchers used descriptive statistics to understand the level of household investments among selected civil servants. To ease the interpretation of mean scores relating to household investments, the researcher used the following range of mean scores to interpret household investments. Mean scores less than 2.500 were interpreted as 'low level of household investment'. Mean scores ranging from 2.500 through 3.500 were interpreted as 'moderate level of household investment'. Mean scores above 3.500 were interpreted as 'high level of household investment'. The standard deviations close to zero indicate consistency of opinions on household investments while standard deviations far away from zero indicate inconsistency of opinions on household investments.

Table 2. Level of Household Investment in Lira city $(N=103)$

\section{Descending means;}

1. I have ever invested in commercial agriculture

2. Some of my income is invested for long term benefit and not only for daily needs

3. I have developed an action plan to meet that target

4. I have set personal investment targets to be met within a particular period e.g. building a 4 door rental within 5 years

5. I have ever invested in buying land

6. I have ever invested in building a rental unit

Average

\begin{tabular}{cc} 
Mean $(\boldsymbol{\mu})$ & Std. Dev. \\
4.330 & 0.797 \\
4.272 & 0.982 \\
4.107 & 0.896 \\
4.097 & 0.798 \\
4.039 & 0.816 \\
3.883 & 0.953 \\
$\mathbf{4 . 1 2 1}$ & $\mathbf{0 . 8 7 4}$ \\
\hline
\end{tabular}

This study examined the level of household investment among selected primary school teachers in Lira city. Accordingly, the level of household investment is high to $(\mu=4.121$; std. dev. $=.874)$, investments in agriculture indicated this $(\mu=4.330$; std. dev. =.797), investments in long-term benefits (mean = 4.272; std. $=.982)$, and developing action plans to meet their targets $(\mu=4.107$; std. dev. $=.896)$. These statistics support the claim that there is high household investment among civil servants. Though it was established that some pockets of disagreements on investments in rental units ( $\mu=3.883$; std. dev. $=.953$ ), there weren't any significant deviations in participants opinions on their household investments. This result supports Sherman and Susan (2013) who suggested that most civil servants take the building of their personal houses as an investment priority. Because personal houses substitute rental units for the employee, the distinction is often not clear.

\section{Inferential statistics}

To establish the relationship between personal savings and household investments, the study adopted correlation tests. Correlation is the statistical technique for measuring the degree of the strength of the relationship between two numerical variables. The method uses the correlation coefficient. Correlation coefficient ranges from 0.00 through 1.00. Correlation coefficients closer to zero indicate a weak relationship while correlations closer to 1.00 indicate strong relationships. When the coefficient is positive, the two variables change in the same direction and if the coefficient is negative, the two variables change in opposite directions.

Table 2. Correlation between personal savings and household investments

\begin{tabular}{llcc}
\hline & & Personal savings & Household investment \\
Personal savings & $\begin{array}{l}\text { Pearson Correlation } \\
\text { Sig. (2-tailed) }\end{array}$ & 1 & \\
Household & Pearson Correlation & -.068 & 1 \\
investment & Sig. (2-tailed) & .493 & \\
$* *$ Correlation &
\end{tabular}

** Correlation is significant at the 0.01 level (2-tailed). 
The correlation reveals that the relationship between personal savings and household investment is very weak and negative $(r=-.037 ; p$-value $=.711)$. The relationship between personal savings and household investments is very weak and negative $(r=-.068 ; p$-value $=.493)$. These statistics imply that civil servants who tend to increase their cash flow are likely to realize some reductions in their level of household investments. Similarly, civil servants who tend to engage in personal savings are likely to register reductions in their level of household investments. Increases in cash flow and personal savings may be used to offset operational expenses and acquisition of other assets which may not necessarily be household investments. The findings agree with Sawsdpeera and Pandey (2012) who established that a greater earnings suggest not just a greater volume of savings but a greater volume of expenditures for their supplementary community overheads that they had to incur for their prestige. Consequently, the amount saved can be greater however the percentage of saving to earnings may not essentially be greater.

The statistics imply that civil servants who struggle to save are likely to see some changes in their household investments, much as the changes observed are likely to be very low. A proper savings culture implies a high level of financial discipline. And since savings are used both for normal expenses and investments, such a civil servant would be inclined to meet both needs i.e. spend and invest. The finding resonates with UNHS (2017), which found that one in every four persons aged 18 years and above $(25 \%)$ who saved did so to buy consumption goods and services while 23 percent saved to pay education expenses. The effective savings culture likely released more money for consumption. Importantly however, the ( $p$-values $>.05$ ), all of which are above 0.05 , imply that the relationships between personal savings and household investments are not statistically significant.

To understand the role of personal savings on household investments, a regression analysis was used. Regression is the mathematical function that relates the independent and dependent variables. In this study, personal savings was the independent variable while household investments was the dependent variable. Regression uses R-Square to measure the role of one variable in the other. The study used RSquare to measure the aggregated effect of personal savings on household investments. Additionally, the study used beta coefficients to measure the impact of a unit change in personal savings constructs on household investments.

Table 4. Regression coefficients

\begin{tabular}{lccccc}
\hline Variable List & \multicolumn{2}{c}{ Unstandardized Coefficients } & \multicolumn{2}{c}{$\begin{array}{c}\text { Standardized } \\
\text { Coefficients }\end{array}$} \\
& $\mathrm{B}$ & Std. Error & Beta & $\mathrm{t}$ & Sig. \\
(Constant) & 4.148 & 0.354 & & 11.714 & 0.000 \\
Personal savings & -0.176 & 0.149 & -0.214 & -1.179 & 0.241 \\
R & 0.206 & & & \\
R Square & 0.043 & & & & \\
Adjusted R Square & 0.014 & & & & \\
Std. Error of the Estimate & 0.439 & & & & \\
\hline
\end{tabular}

Predictors: (Constant), Personal savings, Debt management, Cash flow

Dependent Variable: Household investment

From table 3, it was established that personal savings account for only $4.3 \%$ of the variations in household investments among the civil servants investigated $(\mathrm{R}-$ Square $=.043)$. The effect of personal savings on household investments is indeed very small. This is possibly because there are many areas that civil servants plan to spend their money on. Household investments is just one of them. This suggests that other factors are likely to account for the remaining 95.7\%. This finding concurs with UNHS (2017), which found that civil servants save to acquire assets like houses, vehicles, motorcycles, businesses, and others. Still, they also save for education financing and other consumption activities like weddings, vacations and partying. Personal savings suggests a non-significant effect on household 
investments. For example, $(\beta=-.115 ; p$-value $=.560)$ indicates that a unit-change in personal savings is likely to reduce the level of household investments by $21.4 \%$, according to $(\beta=-.214 ; p$-value $=.241)$. Looking at the significant values (probability estimates), it was found that personal savings does not have a statistically significant relationship with household investments. The statistics generally imply that out of every 100 civil servants in the sample study, less than $95 \%$ are likely to confirm that their current level of household investments is not due to personal savings. Also, civil servants will showcase a household investment level that is above the average. The statistics suggest that household investments among the civil servants investigated are not due to personal savings changes. Civil servants can increase their household investments without any personal savings. This observation is due to the fact that most civil servants undertake their investment decisions without any set long term plan. When the operational household expenses have declined, they will invest the income not used on household investments.

Basing on the probability values ( $p$-value >.05), this study accepted the null hypothesis that personal savings do not significantly affect household investments among the sampled civil servants. The acceptance of the claim implies that the changes in households' investments among civil servants are not due to their personal savings. There could be other factors that rightly account for their stand in household investments. Just like with the rest of the society, civil servants do not invest in households because of personal savings. They just invest on impulse. A finding which agrees with Matewos (2015) who found that lack of financial awareness contributes to poor financial choices and decisions, which can have unfavorable financial and economic implications for individuals, the financial system, and the entire economy, the recent trend in finance and economics has rendered financial planning not just a convenience, but an imperative survival method., and yet financial planning on the African continent by the civil servants is at best low. This is in agreement with NAFPA (2019) which found that $56 \%$ of Americans do not have a financial plan for their future. The majority of Americans are stressed about their financial situations and 1 in 3 Americans do not think they will ever retire.

\section{Testing the hypothesis}

The researcher tested the null hypotheses using the 5\% level of significance. The researcher rejected the null hypothesis when the level of significance was less than 5\%, and accepted the null hypothesis when the level of significance was greater than $5 \%$.

\section{Table 5. Chi-Square test}

\begin{tabular}{lccc} 
Linear association & Pearson Chi-Square & Asymp. Sig. (2-sided) & Decision \\
$\begin{array}{l}\text { Personal savings \& } \\
\text { household investments }\end{array}$ & $247.966(\mathrm{a})$ & .067 & Accept \\
\hline
\end{tabular}

The researcher accepted the null hypothesis that personal savings have no significant effect on household investment among civil servants in Lira Central Division, based on (Asympt. Sig. >.05). The above statistics imply that personal savings do not affect household investments. This is possible because most civil servants have inadequate incomes and cannot meet their financial needs. They have no other alternative than to rely on loans to meet their short-term investments. It was found that personal savings account for a very low proportion of the variations in household investments among civil servants in Lira central division. These findings support Sawsdpeera and Pandey (2012) who studied individual saving factors amongst waged people in Thailand. They established that a greater salary suggests not just a greater volume of saving but a greater volume of expenditures for supplementary social overheads that they have to spend on for their prestige in public. Thus, as revealed by Chappelow (2018), the volume set aside can be greater but the ratio of saving to earnings may not inescapably be greater. In Uganda, saving appears to be high, but what is saved is diverted to consumption than household investments. The study suggests that a unit change in personal savings reduces the level of household investments by $21.4 \%$, looking at $\beta=-.214$ and $\mathrm{p}$-value $=.241$. As previously proposed by Kasalirwe and Lokina (2016), this suggests that personal savings have a non-significant effect on household investments, based on ( $p$-value >.05). 


\section{Conclusion}

The study was about personal savings and household investments in Lira Central Division. Basing on sample results from 103 civil servants who took part in the study, personal savings accounts for a very low effect on household investments among civil servants in Lira City. The non-significant effects of and personal savings on household investments are evidence of this. Similarly, the level of personal savings appeared high when measured in terms of saving practices. However, its aggregated effect on household investments is very insignificant. The divergence in opinions held on important saving practices such as consistently saving a portion of the income monthly confirms this claim. Even among civil servants who struggle to save a portion of their monthly income, less than half of their income goes to savings. Therefore, the study concluded that the level of savings among civil servants in Lira city is inadequate to influence household investment positively.

\section{Limitation and study forward}

This study focussed on personal savings only, and yet other constructs affect household investments. Consequently;

a) Primary school teachers should be organized and trained in financial literacy to handle their finances is planned to meet their asset investment targets.

b) There is still need for further research for primary school teachers and the entire populace to appreciate this very fundamental component of personal savings and financial wealth.

\section{Acknowledgement}

The authors wish to acknowledge the cooperation exhibited by every respondent seeing that data were collected during the period of the Covid-19 pandemic.

\section{References}

Ahimbisibwe, K., and Mafabi, P. (2017, January Thursday). Daily Monitor. Kampala.

ASSP . (2016). Agricultural sector strategic plan, ministry of agriculture, animal industries and fisheries. Kampala.

Bank of Uganda (BoU). (2013). Strategy for financial literacy in Uganda. Kampala.

Chalicha, S. (2015). Empowerment of civil servants through Savings and Credit Cooperative Society (SACCOS): Evidences from Institute of Accountancy Arusha. International Journal of Business and Commerce, 5(09).

Chappelow, J. (2018). Personal savings rate. Retrieved from Investopedia: https://www.investopedia.com/terms/s/savings-rate.asp

CPCU. (2015). Chartered property casualty underwriter. The Institutes (CPCU Society).

Creswell, J. W. (2012). Research design: qualitative, quantitative and mixed methods approaches (4th edition ed.). SAGE Publications Inc.

Cristadoro, K., and Marconi, D. (2012). Household savings in China. 10(3).

Dablar, W. (2014). DALBAR's quantitative analysis of investor behavior. RBC Wealth Management, RBC Capital Markets.

Donaldson, S. J. (2011). Single-fund investment options: portfolio construction simplified for investors . Valley Forge, Pa.

Ellis, K., Lemma, A., and Rud, J. (2010). Investigating the impact of access to financial services on household investment. Westminster, London: Overseas Development Institute.

Finscope. (2018). Report on banking and the status of financial inclusion in Uganda: Insights from FinScope 2018 Survey. Kampala.

G.A.F. (1987). Keynes's theory of investment and saving. in: the Keynesian revolution and its Critics. London: Palgrave Macmillan.

Gliem, A., and Gliem, R. (2003). Calculating, interpreting, and reporting Cronbach's Alpha Reliability coefficient for Likert-Type Scales. Midwest Research to Practice Conference in Adult, Continuing, and Community Education. Science and Education Publishing.

Hilgert, A. M., and Hogarth, M. J. (2002). Household financial management: the connection between knowledge and behavior. Federal Reserve Bulletin. 
Jia, D., Li, R., Bian, S., and Gan, C. (2019). Financial planning ability, risk perception and household portfolio choice. Emerging markets finance and trade, doi: 10.1080/1540496X.2019.1643319

Kasalirwe, F., and Lokina, R. (2016). Financial literacy and household investment choices in Uganda. Kampala.

Keynes, M. (1936). The general theory of employment, interest and money. international relations and security network. Zurich: Palgrave Macmillan .

Kingsley. (2010). Family economics and financial education, 2010: get ready to take charge of your finances using the secrets of saving. University of Arizona.

Krejcie, R.V., and Morgan, D.W. (1970). Determining sample size for research activities. Educational and psychological measurement.

Mario, N. (2019). The principles of investments. the social wellbeing research centre. University of Malaya.

Matewos, R. (2015, Jan). Financial literacy for developing countries in Africa: a review of concept, significance and research opportunities. Journal of African Studies and Development, 8, 1-12. doi:10.5897/JASD2015.0331

MoLHUD. (2016). The Uganda National Housing Policy, 2016: Adequate Housing for All. Ministry of Land, Housing and Urban Development. Kampala.

MoPS. (2019, June - Oct). The Ministry of Public Service Newsletter. (Issue 1).

NAADS. (2017). National Agricultural Advisory Services. Ministry of Agriculture, Animal Industries and Fisheries. Strategic Sector Plan. Kampala, Uganda.

NAFPA. (2019). National Association of Personal Finance Advisors Survey Report.

NSSF . (2018). The National Social Security Fund (NSSF) Post Retirement Survey Report, 2018. Kampala.

Roscoe, S., Eckstein, D., Blome, C., and Goellner, M. (2020). Determining how internal and external process connectivity affect supply chain agility: a life-cycle theory perspective. Production planning \& control, 31(1). 78-91, doi: 10.1080/09537287.2019.1629704

Sawsdpeera, P., and Pandey, I. (2012, March). Determinants of Personal Savings: A study of salaried individuals in Thailand. Afro-Asian Journal of Finance and Accounting, 3(1).

Sherman, D., and Susan, L. (2013). Household investments: still a Man's World?

Stupak, M. (2018). In focus. Congressional research service. Retrieved from www.crs.gov.

Suppakitjarak , N., and P. (2015, March). Household saving behavior and determinants of the forms of saving and investment in Thailand. Journal of Economics, Business and Management, 3(3).

UBOS. (2018). Uganda Bureau of Statistics: Statistical Abstract.

UNHS . (2013). The Uganda National Household Survey. Kampala. Retrieved from https://www.ubos.org/wpontent/uploads/publications/03_20182016_UNHS_FINAL_REPORT. pdf

UNHS . (2017). The Uganda National Household Survey. Kampala.

Young, E. a. (2019). Situational analysis of teachers' payroll, management and capacity building needs assessment for payroll managers under UTSEP. 